\title{
Wesley's Dream Realised in the Methodist Church of Southern Africa: The Ordination of Women Ministers
}

\author{
Mokhele Madise \\ https://orcid.org/0000-0003-1583-860X \\ University of South Africa \\ madismjs@unisa.ac.za
}

\section{Abstract}

John Wesley's famously adopted doctrine was the "priesthood of all believers." This doctrine simply meant that the gospel message was or could not only be preached by a certain group of people, but that it was open to be preached by all who were inspired by the Holy Spirit. This was evident during the 18th century Methodist movement, when women were preachers and acknowledged by John Wesley himself. After John Wesley's death in England, women were missing as both lay preachers and ordained ministers. The Methodist Church also established itself as one of the biggest denominations; however, it had no women ministers or lay preachers at the stage of its establishment. With constant changes, both in political and ecclesial contexts, there was a need for the Methodist Church of Southern Africa (MCSA) to adapt to these changes. This article will discuss the following: background to the women preachers and leaders in the Methodist movement of the 18th century; the advocacy of women ordination in the MCSA; the first white woman clergy; and the first black woman clergy in the MCSA. This would be followed by the influx of other women clergy in the church 40 years later.

Keywords: Methodist Church of Southern Africa (MCSA); John Wesley; women ministers; missionary movement; South Africa

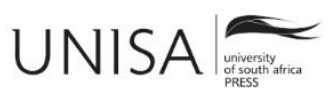




\section{Introduction}

This article focuses on events leading up to the 40-year anniversary of the ordination of women to the ministry in the Methodist Church of Southern Africa (MCSA), recently celebrated in 2015 (Madise and Mtshiselwa 2017, 1). However, there are other historical events which precede the 40-year anniversary of the ordination of women in the MCSA. Some events will derive from the time when the Methodist movement was started in England by John Wesley in the 17th century. The South African political landscape has had a history of exclusion, in particular across racial, ethnic and gender lines. The fact that the society was divided, meant that women were not taken seriously as key role players in social, economic, political as well as religious platforms. This had, in essence, pushed them to become secondary and even tertiary citizens in all the disciplines and aspects of life. Their role was not even regarded as minutely important in any way one could think of. It was only in the late 1960s, when the voices of women started to be audible, that the MCSA began to realise their importance. In this article, the following will be focus areas: background to women's participation in the church; the advocacy of women ordination; the first white clergy woman; and the first black clergy woman, which will lead us to a conclusion.

\section{Methodology}

The methodology that was followed in this article was the qualitative method of research. Primary sources were church archives in the form of the minutes of conferences, which were consulted and used to inform the arguments of this article. The Dimension, as the official MCSA newsletter, secondary sources and publications from articles were also consulted as historical sources to inform the background of events as they were unfolding. No oral interviews were engaged when this article was written.

\section{Background to Women's Participation in the Church}

The participation and leadership of women in the ministry of the Methodist Church can be traced back to early Methodism. It is clear that in early Methodism, women did not conform to the stereotypical patterns of later years, which often saw limitations in female leadership and in religious affairs (Brown 1983, 15). This revealed that the ministries exercised by women in early Methodism were amazing, both in kind and in quality. For these women, it was clear that they possessed a calling to give a public and verbal manifestation of the Christian faith.

According to Brown $(1983,15)$, there are three critical questions which need to be asked: What was the nature of the women's call to speak? What forms did their public speaking take? What opposition did the women face, and how did women defend their behaviour? It is important to briefly look at each of these questions outlined by Brown. 


\section{The Call to Speak}

Few women expressed their desire to respond to the call as well as to speak publicly; a call which in certain instances was identified as the voice of God. In the case of other women, it was an act of compulsion that had power over them. An example of this was Sarah Crosby, who wrote that:

I was praying, my soul was overwhelmed with the power of God; I seemed to see the Lord Jesus before me, and said, "Lord I am ready to follow thee, not only to prison, but to death, if thou wilt give me strength." And he spoke these words to my heart, "Feed my sheep." (Ann Gilbert quoted from Brown 1983, 16)

Another example of an expression by a woman who felt the calling was from Judith Land, who proclaimed that "the experience was that of a person without peace until she consented to preaching to the sinners to repent and turn to God." The call to preach has been connected to some popular demand to confirm the voice of God (Brown 1983, 15). There were many other examples like these two; the most interesting thing is how John Wesley responded to the call by women. John Wesley was impressed by this and in 1787 he wrote:

We give the right hand of fellowship to Sarah Mallet and have no objection to her being a preacher on our connection, so long as she preaches the Methodist Doctrines, and attends to our discipline. (Brown 1983, 19)

Clearly, Wesley was acting either out of character for his time, or he was ahead of his time, where women were hardly afforded space to stand and proclaim their call to the public. It is also difficult to understand the reaction of male counterparts (who were very close to John Wesley) on women taking the podium and even being endorsed by Wesley during the same period.

\section{The Forms of Speaking in Public}

Many women in the 18th century were well aware of the implications of speaking in public; and this included casual conversation and formal preaching. Most of the time, women of this era who spoke publicly, were under the threat of displeasure. The Pauline writings were, for many people of that time, very critical and took the barring of women from speaking in the church seriously. The thought was that any woman speaking publicly on matters of religion, would be questioned. To many, women speaking in public was a matter of avoiding offence. However, women were allowed to speak in public without ascending to the pulpit and preaching from there. The kind of public speaking afforded to women of that time would be to give them space to participate and be involved only in casual conversations with friends. Speaking and praying in cells or class meetings, prayer in society or at other public meetings, testimony, exhortations, expounding, biblical exegesis and application were not allowed for women (Brown 1983, 20). 


\section{Opposition and Women's Defence}

Public speaking for women in the 18th century was inevitable, which provoked strong opposition both inside and outside the Methodist movement (Brown 1983, 25). It was not surprising that opponents quoted biblical texts such as 1 Corinthians 14:34 and 1 Timothy 2:12, which forbid women from speaking in public, especially in the church. However, public speaking at that time took place not only in the Methodist movement, but also in the Quakers movement - and often the former would be confused with the latter. It is no secret that Wesley himself was conservative on the subject of women speaking in public. He wrote a letter to Thomas Whitefield, citing his objection towards the Quaker women, and he too cited the biblical texts (above) by Paul. At that time, women could speak freely in public within the Methodist movement (Lloyd 2009, 39). John Wesley did not have a problem with women on a podium addressing the public, as he had become accustomed to it. This practice of public speaking by women impressed him to the point of acknowledging and modifying his own position. Interestingly, Wesley was the first to authorise women to preach in the Methodist movement in 1761, when Sarah Crosby became the first woman preacher. Wesley wrote a detailed and strongly worded instruction to Crosby and other women, emphasising how they should preach (Tucker and Liefeld 2010). It took a woman, Mary Bosanquet Fletcher, to convince John Wesley to allow women to preach in the Methodist movement. Mary Bosanquet wrote a letter to John Wesley in 1771 as an apologist for women like herself and Sarah Crosby for preaching at an orphanage which she owned. The contents of that letter strongly pushed for women to be allowed to preach in the Methodist movement (Burton 2008). Some of the strong words she used to drive her point home were that "women should be able to preach when they experience an 'extraordinary call,' or when given permission by God" (Chilcote 1993, 78). This was the "straw that broke the camel's back," as Wesley accepted the idea of women speaking and preaching in public and he allowed them to preach in the Methodist movement in 1771 (Lloyd 2009, 34; Mark 2003, 78). In addition, Wesley was encouraged by his mother (Susannah Wesley), who also influenced him to accept women speaking in public; yet history does not acknowledge the role Susannah Wesley played. Susannah Wesley's influence can be argued as not having gone far enough to be recognised as a position John Wesley was commanding in a public space. Historically, John Wesley never intended to establish a church and when he died, he was still an ordained Anglican priest.

\section{Methodism Becoming a Church}

John Wesley never intended to leave the Anglican Church to form another church. In fact, Wesley died a staunch member and priest of the Anglican Church. The refusal by the Bishop of London to ordain a Methodist missionary for the United States of America led to Wesley (as a presbyter) taking the initiative. He ordained Thomas Coke in 1784 as the superintendent, along with Thomas Vasey and Richard Whatcoat, due to his belief in the biblical principle and doctrine of the "priesthood of all believers." This doctrine was not only for Wesley to endorse certain people, but to also ordain missionaries to other lands such as America. John Wesley was himself an ordained priest of the Church 
of England. Later in the same year, John Wesley pronounced the first official Methodist conference of 100 members, who ironically were only men (there were no women delegates), who were to govern the society of the Methodist movement after his death (Davies 2020). John Wesley died in 1791, a time when Methodists were still a movement, and not a church. At this moment in time there were women preachers in the Methodist movement (Burge 1996). The establishment of the church came as a result of the spread of the Methodist movement to other parts of Britain, which extended as far as Scotland, Ireland and Wales; all of which happened in John Wesley's lifetime. After his death, the spread of the Methodist movement was rapid, and it later developed into a church in 1795 (four years after John Wesley's death). This was the result of its split from the Church of England. John Wesley had had no problem with women addressing people in public from the podium, and therefore the newly established church allowed women as both and lay ordained deaconesses and lay preachers in its own structures.

Ironically, the Methodist movement, from its early beginning, had both men and women playing equal roles. However, this changed after its establishment as a church in the late 18 th century, as from then on women were only ordained as deaconesses.

\section{The Methodist Church of Southern Africa and Women Ministry}

The Methodist Church came to South Africa in the same fashion as other Christian denominations (through missionaries), and this was through the Wesleyan Missionary Society. The planting of the church saw the local culture and tradition being pushed to the periphery, while Christianity was becoming the mainstream religion in South Africa.

\section{Advocacy of Women's Ordination}

The Methodist Church in South Africa followed the context of 18th century England, even though there were some differences in terms of origin. In England, during and under John Wesley's leadership, Methodism was not yet a church but a movement. It only became a church when Wesley had already died, and in the church, women were not afforded the space for public speaking and were never ordained or accepted into the ministry, except as deacons. This was also the case regarding the role of women in the church in South Africa. Khumalo $(2016,175)$ argues that in South Africa, the Methodist Church has a history of women fulfilling a role of leadership, which dates back to the days of John Wesley. Women in this context were in actual fact serving in leadership positions only as deacons and in women's groups.

The inception of the Methodist Church in South Africa was through the Wesleyan Missionary Society composed mainly of men (as missionaries), and later black men were roped in as "evangelists." The ministerial development of the Methodist Church continued with the black men being accepted into the ordained ministry, even though not on the same level as their white counterparts. The ministry for black men was historically subjected to bad conditions, which later led to several schisms in the MCSA. 
In the context of South Africa, particularly, there was the dissatisfaction of black ministers regarding their working and living conditions. These schisms gave rise to what is today referred to as African Independent Churches (AICs) in the late 19th and early 20 th centuries respectively. The schisms did not, in any way, end the experiences of the ministry in the Methodist Church, but played a significant role towards the emergence of the struggle for the ordained ministry of women, especially within the mainline denomination. The struggle assisted in the breaking down of gender barriers within the Methodist Church in South Africa. One thing that is of note, is its recurrence in a different geographic and political context, with a different tradition and culture to that of England. The social, political and economic landscapes were different from those of the 18th century England. In spite of all these differences, it is important to take note of the similarities brought about by the influences of patriarchal dominance. Over the years that the Methodist Church had established itself as a church, its ministry and leadership had always been in the hands of men. It was only in 1963 that women were accepted in the ministry as deaconesses, but not at the same level as the ministry occupied by men. Mkhwanazi and Kgatla $(2015,185)$ argue that the entry level of women as ministers in the MCSA was at the deaconess level, and this ministry was mainly joined by white women. The training of these women as deaconesses was done in England at the Wesley Deaconess College, after which they would be ordained as deaconesses (the History of the Methodist Diaconial Order, n.d.). Some institutions that trained the deaconesses were Tottenham Deaconess Institute and the Stephenson's Wesley Institute (Aitchison 2003, 34). Their journey into this ministry was set around certain rules and regulations applicable to male candidates, with a three-year probation from the day of graduation, before receiving ordination.

The debate to accept women into the full ministry of the Methodist Church was provoked by Jack Cook in 1973. Cook was a Methodist minister and at the same time a warden of the Deaconess Order. He tabled this as a matter for discussion regarding the ordination of women who were deaconesses. There were mixed reactions, as some ministers welcomed the idea, while it did not go down well with other ministers (Khumalo 2016, 176). The latter demonstrated the level and power of patriarchy that was prevalent in the MCSA. It took the MCSA some time to accept the first woman into the ordained ministry, only when this matter was finally passed as a conference resolution in 1975. The Methodist Church in England originally never accepted women in the ministry when it was formed late in the 18th century, after the time of Wesley. It is understandable why it took the MCSA some time to engage with the matter of ordaining women as ministers. After few years (1973 to 1975) of deliberations around the matter, the first woman to respond to the call of ordained ministry was Constance Oosthuizen in 1976. Oosthuizen was ordained in 1976 and her station was Port Shepstone, where she served her vocation as a minister until retirement in 1997. Oosthuizen's ordination as the first woman in the ministry of the MCSA successfully opened doors for many other women to respond to their call for the ordained ministry (Khumalo 2016, 175). Oosthuizen has left an indelible mark as the first woman to be ordained in the Methodist Church (New Dimension 2016, 7). 
For black women, the journey to enter the ordained ministry of the MCSA may have taken a while, as Mavis Mbilini joined 10 years after Constance Oosthuizen. This was not due to any political influence or rules and regulations of the church, but this could possibly be that women of that time were not ready. However, after Mbilini, there have been a significant number of women across racial lines entering the ordained ministry of the MCSA.

\section{First Woman Clergy in the Methodist Church of Southern Africa}

Many scholars in theological circles within South Africa recognise that the first woman to enter the ordained ministry of the Methodist Church was Constance Oosthuizen in 1976, and before that she was a deacon since 1955 until she was finally ordained after 21 years as a deaconess (Oosthuizen 1990). A decade later, Mavis Mbilini, who was also a deacon, was the first black woman to be admitted into the full ministry of the Methodist Church. Phemelo Marumo $(2017,7)$ consciously argues that the MCSA only came to recognise the importance of women in the ministry when it opened its doors for them (women) to be ordained after 160 years of its existence. This statement by Marumo is heavily loaded, as it implies that the MCSA failed to recognise that John Wesley came to understand the significant role women played in the development of the church. The latter can be argued as a fundamental failure on the part of the Methodist Church to fulfil the quest and dream of John Wesley as the father and founder of the Methodist community. One could easily deduce this from Wesley's recognition of Sarah Crosby, who became the first lay preacher in 1761 after being granted permission by John Wesley. Though John Wesley recognised the role women played in the church, he never really managed to get a single woman to be ordained as a minister during his lifetime. Despite this, Wesley was in his own right a reformer of the role of women in ministry. Khumalo $(2016,177)$ puts it correctly when he argues that Wesley presumed that Paul was forbidding women from peaching, but his involvement proved that women were powerful preachers. As a result, Wesley allowed women with a calling to bear their testimony, but they were not allowed to preach. However, he (John Wesley) acknowledged the role of women and encouraged them to preach in meetings. In this way, John Wesley could be viewed as a dreamer, though it may not have been his personal dream to be achieved during his life time. He was a precursor, ahead of his time, when he licensed women to preach in a context that earned him criticism both inside and outside of the Methodist movement. It is no coincidence that towards the end of his ministry and life, Wesley began ordaining women into the ministry; two of those were Sarah Crosby and Sarah Mallet as preachers (Tucker and Liefeld 2010, 240).

\section{No Woman Leader in the Methodist Church of Southern Africa}

The argument above, especially with reference to South Africa, can be expanded to imply that it was an embarrassment after John Wesley was confronted by another woman, Mary Bosanquet Fletcher, on their exclusion (www.library.manchester.ac.uk). The Methodist Church continued to live, exist and function without the shame of realising how it had degraded women to secondary Christian citizens for many years. It 
is no coincidence that the former General Secretary of the MCSA, Charmaine Morgan, made that famous statement in 2015 when addressing the conference, that after 40 years of being in the ministry as women clergy, male clergy still failed to recognise the vacuum in the leadership of the church without a woman (Minutes of Conference MCSA 2016, 16-26; Methodist Church Yearbook 2016). The assertion by Charmaine Morgan should be viewed in the broader context, that leadership positions in the church were generally inaccessible to women from the circuit level as superintendents to those of authority (District Bishop to the Connexional Presiding Bishop) of the MCSA. From Wesley's lifetime, the Methodist family was made conscious of the presence and role women could play in the church. Though Sarah Crosby might have been preaching to the orphans at an orphanage home in London, the recognition of women's role in the church and public space was granted by Wesley. The context might not have been the same, but there was a resemblance in the events within South Africa, taking into consideration the experience of Constance Oosthuizen who was a deacon in the MCSA. John Wesley had already laid the foundation and it was upon those church leaders after him to run with the baton and fulfil the dream.

\section{A Dream Realised in South Africa: A Coincidence}

The founding of the Methodist movement in the 18th century by John Wesley, along with his brother Charles and a friend, George Whitefield, was in itself the realisation of a dream by John Wesley. At the same time, the Methodist Church in England ordained its first woman minister on 2 July 1974 in Bristol. It was no coincidence that this happened at almost the same time, though it may have been a year later in this context (www.library.manchester.ac.uk).

John Wesley's dream was equally and finally realised in South Africa, when women were admitted into the full ministry of the Methodist Church. The 40-year anniversary celebration of women in the ministry of the MCSA happened a year later than that of Great Britain, and this was a milestone in the life and history of the MCSA and Great Britain. The South African context played a role in realising John Wesley's dream, when Jack Cook saw what Constance Oosthuizen had achieved as a deaconess. It is Constance Oosthuizen's work in Johannesburg that broke the camel's back and influenced Jack Cook to table, before the conference of the Methodist Church, a motion to admit women into the ordained ministry (Khumalo 2016, 46). Jack Cook, as both a minister in the church and warden of the Deaconess Order, was moved by what Oosthuizen had managed to achieve as a deacon. Oosthuizen was able to build congregations and put up church structures and church halls around Johannesburg, yet she was not an ordained minister in the church. In brief, Constance Oosthuizen was able to break down the barriers which stated that women could not lead, and she led through her ministry as a deacon and a woman. The 1975 resolution by the conference to admit women into the ordained ministry, was John Wesley's realised dream in South Africa; a dream which subsequently allowed many women to speak and preach in churches and public spaces. 


\section{Conclusion}

In conclusion, the main argument of this article is to demonstrate that the ministry for women in the MCSA was a response to their call, and an expression of their wish to exercise their spirituality as equal role players in the church. Not only were they interested in wearing the clerical collar and standing in the pulpit, but this was ministry appropriating the full cycle of an evangelical call, without any form of prejudice. It allowed them to engage in deconstructing the myth of gender biases and reconstructing gender equity in the ordained ministry, thereby making the dream of John Wesley a reality. The number of ordained women in the ministry of the Methodist Church has grown significantly since 1975 in the MCSA, and continues to grow.

\section{References}

Aitchison, R. J. 2003. "The Overseas Mission of the Wesley Deaconess Order: Theological Aberration or Inspiration?" MMin dissertation, Potchefstroomse Universiteit vir Christelike Hoër Onderwys, in association with Greenwich School of Theology UK.

Brown, E. K. 1983. Women of Mr Wesley's Methodism. Studies in Women and Religion. New York: Edwin Mellen.

Burge, J. 1996. Women Preachers in Community: Sarah Ryan, Sarah Crosby, Mary Bosanquet. Foundery Press.

Burton, V. T. 2008. Spiritual Literacy in John Wesley's Methodism: Reading, Writing, and Speaking to Believe. Baylor University Press.

Chilcote, P. W. 1993. She Offered the Christ: The Legacy of Women Preachers in Early Methodism. Eugene, O.R: Wipf and Stock.

Davies, R. E. 2020. Methodism. Accessed April 17, 2020. https://www.britannica.com/topic/Methodism.

Khumalo, S. 2016. "From Constance Oosthuizen to Purity Malinga: The struggle for equality in ordination in the Methodist Church of Southern Africa." Studia Historiae Ecclesiasticae 42 (2). Pretoria: Unisa Press. https://doi.org/10.17159/2412-4265/2016/1413.

Lloyd, J. 2009. Women and the Shaping of the British Methodism: Persistent Preachers, 18071907. Manchester University Press. https://doi.org/10.7228/manchester/9780719078859.001.0001.

Madise, M., and N. Mtshiselwa. 2017. Studia Historiae Ecclesiasticae, special edition. Pretoria; Unisa Press.

Mark, E. A. 2003. Women in God's Army: Gender and Equality in the Early Salvation Army. Waterloo, Ont: Wilfrid Laurier University Press. 
Marumo, P. O. 2017. "A Call for the Recognition and Empowerment of Women in the Ministry of the Methodist Church of Southern Africa." In Reaching a Milestone: Forty Years of Ordaining Women in the Methodist Church of Southern Africa, special supplement, edited by M. Madise and N. Mtshiselwa N. Pretoria: Unisa Press. https://doi.org/10.25159/2412-4265/1504.

Minutes of Conference Methodist Church of Southern Africa, 2016. Cape Town: Methodist Publishing House.

Mkhwanazi, F. S., and T. Kgatla. 2015. "The Place of Women Ministers in the Methodist Church of Southern Africa”. Studia Historiae Ecclesiasticae 14 (2). Pretoria: Unisa Press. https://doi.org/10.17159/2412-4265/2015/130.

New Dimension. Celebrating the Rev. Constance Oosthuizen. 2016. New Dimension 47(7): 1.

Oosthuizen, C. 1990. Conquerors through Christ. Cape Town: Calvin and Sales.

The Methodist Church of Southern Africa 2016 Yearbook. Cape Town: Methodist Publishing House.

Tucker, R., and W. L. Liefeld. 2010. Daughter of the Church: Women and Ministry from New Testament Times to Present. The Grand Rapids: Academia Books.

www.library.manchester.ac.uk. Accessed April 20, 2020. "The Role of Women within Methodism.” University of Manchester Library. 9 September 2020. 